\title{
Article \\ How Might World Heritage Status Support the Protection of Sacred Natural Sites? An Analysis of Nomination Files, Management, and Governance Contexts
}

\author{
Bas Verschuuren ${ }^{1, * \mathbb{D}}$, Alison Ormsby ${ }^{2} \mathbb{D}$ and Wendy Jackson ${ }^{3}$ \\ 1 Forest and Nature Conservation Policy Group, Wageningen University \& Research, Droevendaalsesteeg 4, \\ 6708 PB Wageningen, The Netherlands \\ 2 Department of Environmental Studies, University of North Carolina Asheville, 1 University Heights, \\ Asheville, NC 28804, USA; aormsby@unca.edu \\ 3 New Zealand Ministry of Foreign Affairs and Trade, 195 Lambton Quay, Wellington 6011, New Zealand; \\ wendy.jackson@mfat.govt.nz \\ * Correspondence: bas.verschuuren@wur.nl
}

check for updates

Citation: Verschuuren, B.; Ormsby, A.; Jackson, W. How Might World Heritage Status Support the Protection of Sacred Natural Sites? An Analysis of Nomination Files, Management, and Governance Contexts. Land 2022, 11, 97. https:// doi.org/10.3390/land11010097

Academic Editors: Hannes Palang and Bastian Bertzky

Received: 3 November 2021 Accepted: 28 December 2021

Published: 7 January 2022

Publisher's Note: MDPI stays neutral with regard to jurisdictional claims in published maps and institutional affiliations.

Copyright: (c) 2022 by the authors. Licensee MDPI, Basel, Switzerland. This article is an open access article distributed under the terms and conditions of the Creative Commons Attribution (CC BY) license (https:// creativecommons.org/licenses/by/ $4.0 /)$.

\begin{abstract}
This study provides an overview of how sacred natural sites are given recognition within the World Heritage system. It offers an analysis of the extent to which sacred natural sites that are part of nine World Heritage sites are recognised in site nomination files, management plans, and governance of these sites. The World Heritage sites are located across all continents except for Antarctica. We analysed sites in Australia, Greece, Guatemala, India, Japan, Kenya, Malaysia, New Zealand and the Russian Federation. We found that the cultural and spiritual significance of sacred natural sites is under-recognised, especially in natural World Heritage sites. In addition, Indigenous and religious custodians are frequently excluded from site management and governance. We make four recommendations for improving the recognition of sacred natural sites and the involvement of their custodians in the World Heritage process and in site nomination, governance, and management: (1) identification and recognition of sacred natural sites including their associated cultural and spiritual values; (2) recognition of, and articulated roles for custodians of sacred natural sites in the governance and management of World Heritage sites; (3) increased uptake of religious groups and Indigenous Peoples' conservation approaches to the joint management of World Heritage sites that contain sacred natural sites, and (4) prevention of exclusion of custodians and ecological migration by applying inclusive conservation practices through rights-based approaches.
\end{abstract}

Keywords: sacred natural sites; World Heritage sites; spiritual values; cultural values; intangible values; protected areas; heritage conservation; biocultural conservation

\section{Introduction}

This study analyses nine World Heritage sites to assess if and how sacred natural sites have been recognised and integrated in the sites' nominations, management, and governance. Particular attention is given to the role of sacred natural site caretakers and stewards, called custodians. The article commences with an overview of sacred natural sites in the context of the World Heritage Convention. This overview is followed by a section on materials and methods. The results are detailed in separate descriptions of each World Heritage site. This is followed by a discussion enriched with findings from academic and policy documents. At the end of the article, conclusions are drawn, and recommendations are made for improving recognition of sacred natural sites and their custodians in World Heritage processes and site management.

\section{Context of World Heritage and Sacred Natural Sites}

The Convention Concerning the Protection of the World Cultural and Natural Heritage, commonly known as the World Heritage Convention, entered into force in 1972 [1]. There 
are currently 1154 properties inscribed on the World Heritage list: 897 cultural properties, 218 natural properties, and 39 mixed properties. Nearly half (545) of the properties are in Europe and North America, with the fewest in the Arab States (88) and Africa (98); there are 146 in Latin America and the Caribbean, and 277 in Asia and the Pacific.

While the Convention's main objective is to ensure the identification, protection, conservation, presentation, and transmission of cultural and natural heritage to future generations, it makes little reference to sacred natural sites. In 2008, UNESCO and IUCN published guidelines for protected area managers and defined sacred natural sites as "areas of land or water having special spiritual significance to peoples and communities" [2] (p. 7). In 2010, UNESCO initiated a programme for the management of World Heritage sites of religious interest [3]. Despite offering helpful starting points for the recognition of sacred natural sites, both initiatives have had little measurable impact on site nominations to date. The extent to which the initiatives have contributed to management interventions on the ground is less known. This may change, as sacred natural sites and related cultural and spiritual values have been included as a criterion for evaluation in the World Heritage Conservation Outlook Assessments [4].

The Convention is implemented through the nomination and inscription of World Heritage sites-natural sites, cultural sites, mixed sites, or cultural landscapes. For a sacred natural site to be recognised in the nomination file of a World Heritage site, its values have to directly contribute to the Outstanding Universal Value (OUV) of the potential site. OUV is defined as:

“... Cultural and/or natural significance which is so exceptional as to transcend national boundaries and to be of common importance for present and future generations of all humanity. As such, the permanent protection of this heritage is of the highest importance to the international community as a whole" [5] (Para. 49).

To demonstrate OUV, sites must meet at least one of ten specific criteria, although often sites meet more than one criterion (see Table 1). Properties are assessed by specific technical advisory bodies that make recommendations to the World Heritage Committeethe International Council on Monuments and Sites (ICOMOS) for cultural criteria and the International Union for the Conservation of Nature (IUCN) for natural criteria. This may lead one to think that sacred natural sites are at risk of falling between the cracks of separate natural and cultural heritage practices. Sites nominated based on cultural criteria where sacredness is vested in man-made structures set in natural ecosystems may receive recognition more easily than sites nominated based on natural criteria, which contain culturally significant and sacred natural features. However, the recognition of sacred natural sites within the World Heritage nomination files depends on whether they are of recognised OUV. Safeguarding OUV presumes safeguarding of other heritage values that are of national, regional, or local importance [6]. These can be values related to sacred natural sites included in World Heritage sites' management plans. This, however, does not guarantee the recognition of sacred natural sites nor the inclusion of their custodians in governance and management arrangements.

Table 1. Criteria for nomination and inscription of World Heritage Sites [7].

\begin{tabular}{|c|c|}
\hline Nature of Criteria & Details of Criteria \\
\hline Cultural & (i) to represent a masterpiece of human creative genius \\
\hline Cultural & $\begin{array}{l}\text { (ii) to exhibit an important interchange of human values, over a } \\
\text { span of time or within a cultural area of the world, on } \\
\text { developments in architecture or technology, monumental arts, } \\
\text { town-planning or landscape design }\end{array}$ \\
\hline Cultural & $\begin{array}{c}\text { (iii) to bear a unique or at least exceptional testimony to a cultural } \\
\text { tradition or to a civilisation that is living or which } \\
\text { has disappeared }\end{array}$ \\
\hline
\end{tabular}


Table 1. Cont.

\begin{tabular}{|c|c|}
\hline Nature of Criteria & Details of Criteria \\
\hline Cultural & $\begin{array}{l}\text { (iv) to be an outstanding example of a type of building, } \\
\text { architectural or technological ensemble or landscape, which } \\
\text { illustrates (a) significant stage(s) in human history }\end{array}$ \\
\hline Cultural & $\begin{array}{l}\text { (v) to be an outstanding example of a traditional human } \\
\text { settlement, land-use, or sea-use that is representative of a culture } \\
\text { (or cultures) or human interaction with the environment, } \\
\text { especially when it has become vulnerable under the impact of } \\
\text { irreversible change }\end{array}$ \\
\hline Cultural & $\begin{array}{l}\text { (vi) to be directly or tangibly associated with events or living } \\
\text { traditions, with ideas, or with beliefs, with artistic and literary } \\
\text { works of outstanding universal significance }\end{array}$ \\
\hline Natural & $\begin{array}{l}\text { (vii) to contain superlative natural phenomena or areas of } \\
\text { exceptional natural beauty and aesthetic importance }\end{array}$ \\
\hline Natural & $\begin{array}{l}\text { (viii) to be outstanding examples representing major stages of } \\
\text { earth's history, including the record of life, significant ongoing } \\
\text { geological processes in the development of landforms, or } \\
\text { significant geomorphic or physiographic features }\end{array}$ \\
\hline Natural & $\begin{array}{l}\text { (ix) to be outstanding examples representing significant ongoing } \\
\text { ecological and biological processes in the evolution and } \\
\text { development of terrestrial, fresh water, coastal and marine } \\
\text { ecosystems and communities of plants and animals }\end{array}$ \\
\hline Natural & $\begin{array}{l}\text { (x) to contain the most important and significant natural habitats } \\
\text { for in-situ conservation of biological diversity, including those } \\
\text { containing threatened species of outstanding universal value } \\
\text { from the point of view of science or conservation }\end{array}$ \\
\hline
\end{tabular}

Interactions between natural and cultural heritage were articulated in the World Heritage system in 1992, when the Operational Guidelines were revised to include 'cultural landscapes' [8] (p. 58). Three categories of cultural landscapes were identified: (1) clearly defined landscape designed and created intentionally by man; (2) organically evolved landscape; and (3) associative cultural landscape. This last category arguably offers the best coverage for sacred natural sites [9]. Landscapes can be inscribed as World Heritage sites, provided they meet at least one of these criteria. The connection between people, culture, and World Heritage was further strengthened in 2007, when the World Heritage Committee agreed to expand the strategic objectives to include communities at the same level as other strategic objectives within the World Heritage system [10]. The importance given to local communities should in principle make it easier to focus World Heritage nominations as well as their management on sacred natural sites. However, the Convention does not have a human rights framework but is gradually moving toward incorporating rights-based approaches [11].

Sacred natural sites can be seen as protected or conserved areas in their own right, illustrating the intricate connections between indigenous, local and religious communities, cultural heritage, and natural heritage. Despite this notion, the recognition of sacred natural sites as a separate protected area category or governance type of protected area did not materialise [12]. In 2008, the IUCN Guidelines for Protected Area Categories [13] recognised that sacred natural sites exist in all IUCN categories of protected area (i.e., IUCN categories I-VI) and in areas subject to all governance types: (a) governance by government, (b) co-managed protected areas; (c) private protected areas; and (d) Indigenous and local community conserved areas. As sacred natural sites exist in all IUCN protected areas categories across the world, they intersect with different and potentially overlapping international designations. Indeed, several scholars have pointed out that many protected areas, and specifically World Heritage sites, have been purposefully established over 
existing sacred natural sites because of their biological values, which were often conserved through biocultural approaches based on their cultural and spiritual significance [14-17].

Despite the clear link between World Heritage sites and sacred natural sites, there is no explicit reference to sacred natural sites (or even sacred sites) in the Convention's Operational Guidelines. Ekern et al. [18] observed that many expressions of sacred or religious significance might not meet the criteria for OUV required for nomination of a site as World Heritage property. We argue that the unique values of sacred natural sites may be under-recognised because their significance may not be well-understood or they are consciously downplayed by State parties for political reasons [19]. An example of this could be the nomination of both the Golden Mountains of Altai and the Western Ghats under solely natural criteria. In the case of the Golden Mountains, this nomination left no space for Indigenous custodians to use the World Heritage Convention as a space to object against the state government supported gas pipeline being developed at the site, potentially damaging many significant sacred natural sites [20]. Cultural and spiritual values can-and often do-play an important role in the governance and management of a site, and we argue that this importance should be explicitly re-evaluated in the context of World Heritage nominations and operational guidelines.

\section{Materials and Methods}

The World Heritage sites included in this study provide the empirical data that the authors used in our analysis. The authors deliberately selected nine World Heritage sites from across a global range of geographical locations. Selection was performed nonrandomly in order to ensure representation of the various criteria under which the World Heritage sites were inscribed and their dates of inscription (see Table 2). Between the authors, all sites were visited, except for the Golden Mountains of Altai in the Russian Federation. These experiences have provided the authors with insights and information on sacred natural sites in these particular World Heritage sites.

In addition to the field visits, the findings of this research are based on the analysis of academic and grey literature consisting of management plans and World Heritage site nomination files. We analysed eight management plans and the nomination files, including the site evaluation reports of all nine sites. The nomination file for Tikal National Park could not be analysed because it is not publicly available, possibly due to its early inscription date. Notably, Mount Athos has a public nomination file, but not all pages of the file have been included. In addition, the management plan of Mount Athos was not publicly available at the time of publishing this article. Member states of the World Heritage Convention are not obliged to submit site management plans to the World Heritage Committee although this is increasingly seen as a sign of good practice.

The results presented in this article are also supported by an analysis of academic literature. The academic literature used relates to the specific World Heritages sites selected for this article, as well as to the practices and politics of the World Heritage Convention in general. A growing body of literature on the management and governance implications of sacred natural sites in protected and conserved areas was also consulted. Because the site selection is not comprehensive, a systematic literature review covering all World Heritage sites has not been carried out.

The authors recognise that the study does not provide sufficient empirical basis for the conclusions and recommendations to be equally relevant to all other World Heritage sites. These cases and examples are not meant to be comprehensive but rather to give an overview of the range and variety of sacred natural sites that are also part of World Heritage sites. Therefore, the emphasis is on their importance to the way World Heritage sites are nominated, managed and governed from the international to the local level. 
All sources have been triangulated as much as possible in order to strengthen the validity of our results [21]. This way, the analysis of the case studies along with a review of the management plans and technical documents for each site deliver a rich basis for answering the question about how World Heritage sites may or may not support the protection of sacred natural sites.

Table 2. World Heritage sites with sacred natural sites covered in this study.

\begin{tabular}{|c|c|c|c|c|c|}
\hline Country & $\begin{array}{c}\text { World Heritage } \\
\text { Site }\end{array}$ & Size (ha) & Inscription & $\begin{array}{c}\text { Criteria } \\
\text { (see Table 1) }\end{array}$ & $\begin{array}{c}\text { Sacred } \\
\text { Natural Site }\end{array}$ \\
\hline Australia & $\begin{array}{c}\text { Kakadu National } \\
\text { Park \# }\end{array}$ & $1,980,995$ & 1981 & $\begin{array}{l}\text { (i) (vi) (vii) } \\
\text { (ix) (x) }\end{array}$ & $\begin{array}{c}\text { Rock art sites, } \\
\text { dreaming } \\
\text { sites }\end{array}$ \\
\hline Greece & Mount Athos \# & 75,370 & 1988 & $\begin{array}{l}\text { (i) (ii) (iv) } \\
\text { (v) (vi) (vii) }\end{array}$ & $\begin{array}{c}\text { Sacred } \\
\text { Mount Athos }\end{array}$ \\
\hline Guatemala & $\begin{array}{c}\text { Tikal National } \\
\text { Park \# }\end{array}$ & 795,315 & 1979 & $\begin{array}{l}\text { (i) (iii) (iv) } \\
\text { (ix) }(\mathrm{x})\end{array}$ & $\begin{array}{l}\text { Sacred sites } \\
\text { in the Tikal } \\
\text { and wider } \\
\text { Petén area }\end{array}$ \\
\hline India & Western Ghats & 795,315 & 2012 & (ix) (x) & $\begin{array}{c}\text { Numerous } \\
\text { sacred groves }\end{array}$ \\
\hline Japan & $\begin{array}{l}\text { Shrines and } \\
\text { Temples of } \\
\text { Nikkō }\end{array}$ & $\begin{array}{l}\text { Core zone: } \\
50.8 \text { buffer } \\
\text { zone: } 373.2\end{array}$ & 1999 & $\begin{array}{l}\text { (ii) (iii) (iv) } \\
\text { (vi) }\end{array}$ & $\begin{array}{c}\text { Sacred } \\
\text { mountains }\end{array}$ \\
\hline Kenya & $\begin{array}{c}\text { Sacred Mijikenda } \\
\text { Kaya Forests * }\end{array}$ & 795,315 & 2008 & (iii) (v) (vi) & $\begin{array}{l}\text { Mijikenda } \\
\text { kaya forests }\end{array}$ \\
\hline Malaysia & Kinabalu Park & 75,370 & 2000 & $(\mathrm{ix})(\mathrm{x})$ & $\begin{array}{c}\text { Sacred } \\
\text { Mount } \\
\text { Kinabalu }\end{array}$ \\
\hline $\begin{array}{c}\text { New } \\
\text { Zealand }\end{array}$ & $\begin{array}{c}\text { Tongariro } \\
\text { National Park *\# }\end{array}$ & 79,596 & 1990 & (vi) (vii) (iii) & $\begin{array}{l}\text { Sacred } \\
\text { mountain }\end{array}$ \\
\hline $\begin{array}{l}\text { Russian } \\
\text { Federation }\end{array}$ & $\begin{array}{c}\text { Golden } \\
\text { Mountains of } \\
\text { Altai }\end{array}$ & $1,611,457$ & 1998 & $(\mathrm{x})$ & Ukok plateau \\
\hline
\end{tabular}

\section{Results}

In this section, nine World Heritage sites are described, with emphasis on elements relevant to the sacred natural sites and their traditional custodians. Key data on the sites such as dates of inscription, nomination criteria and the mention of sacred (natural) sites and their custodians in the nomination files and management plans are summarised in Table 2. Each of the nine sites is presented alphabetically by country below.

\subsection{Kakadu National Park, Australia}

Kakadu National Park has been continuously occupied by Indigenous peoples for 50,000 years and contains many natural sites that are sacred to Indigenous peoples associated with rocks, rivers, and water holes. These include ceremonial and dreaming sites that mark the events of mythical ancestral beings that created the land at the beginning of time [22]. Reports from IUCN and ICOMOS mention cultural values and rituals associated with the area $[23,24]$.

The site was inscribed in 1981 and extended in 1987, 1992, and 2011 when, after decades of lobbying by Jeffrey Lee, Koongarra's senior custodian, Koongarra land previously excluded because of its uranium resources was included. Lee observed [22] (p. 1): 
"I want to ensure that the traditional laws, customs, sites, bush tucker, trees, plants and water at Koongarra stay the same as when they were passed on to me by my father and great grandfather. Inscribing the land at Koongarra as World Heritage is an important step in making this protection lasting and real."

The 10-year management plan for the park [25] is explicit in recognising the Indigenous custodians-Bininj/Mungguy-as well as their connection to the land and their ongoing role in operation and co-management of the park. One of the guiding principles in the plan is: "culture, country, sacred places and customary law are one, extend beyond the boundaries of Kakadu, and need to be protected and respected" [25] (iii). Furthermore, the plan's values statement is explicit about the importance of Bininj/Mungguy in the park's operation: "The park is first and foremost home to Bininj/Mungguy. The long and continuing history of Bininj/Mungguy custodianship of Kakadu is one of the most important things about the park" [25] (p. 10). The plan contains details about Aboriginal creation myths tied to the land, clan estates and traditional owners, and kinship relationships. In a section on the World Heritage status of Kakadu National Park, the plan indicates an intention to balance tourism and livelihood opportunities with the need to protect cultural values.

\subsection{Mount Athos, Greece}

Mount Athos, or the Holy Mountain, is located at the Athos Peninsula in the Aegean Sea and has been the spiritual centre of Orthodox Christianity since 984 [26]. The Holy Mountain has been classified by the Orthodox Church as an ecumenically sacred place where the unique truths of Christ's Gospel and church have been experienced [27]. The Holy Mountain was designated a mixed World Heritage site in 1988 and later it was included in the Natura 2000 network [28]. While the World Heritage nomination file is only partly publicly available [29], the ICOMOS Advisory Body describes "the transformation of a mountain into a sacred place" [30] (p. 2). A management plan is not yet available in the public domain, and it remains uncertain if it has been completed. Philippou and Kontos [27] (p. 123) describe the embodied sacredness of Mount Athos as a duty of care:

"The monks of the Holy Mountain have dedicated their lives to worshipping the Divine, and this is also expressed through the preservation of the natural environment in which they live. The Holy Community respects the natural surroundings of the area and is aware of the importance of nature, which it considers a gift from God".

The Holy Mountain is home to 20 monasteries renowned for their architecture and artefacts. The monastic communities also accumulated cultural knowledge, a Byzantine musical tradition, unique painting traditions ranging from wall paintings to portable icons, gold objects, embroideries and illuminated manuscripts, and the traditional way of using natural resources [28]. All of these constitute its cultural importance and contribution to global world heritage.

While the Hellenic Ministry of Culture and Sports is responsible for the property management at Mt. Athos, the peninsula has been recognised as an autonomous and self-governed site since its first constitution was signed in 972 [28]. The peninsula is only accessible to men; women, children, and female domesticated animals have been excluded, with the exception of cats.

\subsection{Tikal National Park, Guatemala}

Tikal National Park in Guatemala, inscribed on the World Heritage list in 1979, is located in Central America's largest forest region, which extends into neighbouring Mexico and Belize. Tikal is considered to be an exceptional place of cosmological connotations and was considered to have been a "stage" for theatrical representations [4]. Tikal reflects the cultural evolution of Mayan society from hunter-gathering to farming, with an elaborate religious, artistic and scientific culture [31]. The site is recognised for its extraordinary 
biodiversity and archaeological importance. It is a place where human beings coexisted with their environment as demonstrated by architectural and artistic remains of the Mayan civilisation from 600 BCE up to the collapse of the urban centre around 900 CE [31]. The ceremonial centre contains superb temples and palaces and public squares accessed by means of ramps.

The nomination file for the property is not available; however, in their evaluations of the nomination file, both Advisory Bodies commented on both cultural and biological elements of the site. ICOMOS noted the site is "fundamental for Pre-Columbian archaeology and for the protection of nature" [31] (p. 1), whereas IUCN stated that Tikal "is first and foremost a cultural site; it also represents a poorly understood relationship between man and nature" [32] (p. 1).

The property is managed by Guatemala's National Council of Protected Areas and the National Institute for History and Anthropology; management and conservation are strategically guided by a Master Plan [33]. The site's cultural and spiritual use by current Indigenous spiritual guides is regulated by the management authorities on the basis of the 1977 Peace Accords, which state that Indigenous people shall have access to their cultural and sacred places, including those located in archaeological monuments [33] (p. 44).

The boundaries of Tikal National Park are identical to the World Heritage site, but there have been intentions to consider additional adjacent forest areas to be covered by a possible extension of the property. Nonetheless, several threats such as weathering of glyphs and murals, illegal looting, and touristic over-use are critical issues that need to be addressed by holistic, sustained, long-term conservation. Ongoing negotiation is needed between the site managers, other governmental institutions, local communities, and Indigenous spiritual guides in order to recognise the latter as a critical management priority in the context of the cultural and spiritual aspects of the site according to the latest World Heritage Outlook [4].

\subsection{Western Ghats, India}

The Western Ghats is a mountainous biodiversity hotspot region situated parallel to the west coast of India. Because numerous shrines and sacred groves exist throughout the region, it is a natural serial World Heritage inscription covering 39 components grouped into clusters around protected areas, crossing six states: Karnataka, Kerala, Tamil Nadu, Goa, Maharashtra, and Gujarat [34]. The site was inscribed in 2012. Although the nomination document for the site focuses on the biological characteristics of the Western Ghats, it also includes culture-relevant language. Examples include: "The sacred groves are a biological heritage, conserved largely as a cultural and religious tradition" [34] (p. 10); and "There are about 2000 sacred groves spread across these mountain ranges" [34] (p. 65). The sacredness of the Cauvery River is also noted in the nomination document.

The property is managed by the Western Ghats Natural Heritage Management Committee under the auspices of India's Ministry of Environment and Forests. All 39 components in the seven sub-clusters are managed under specific management/working plans. Livelihood concerns of the local communities are regulated by relevant legislation, as well as their participation in Village Ecodevelopment Committees.

Numerous studies have been conducted about the biodiversity and cultural values of the sacred groves of the Western Ghats, and documenting that the protected area network was insufficient to protect the unique endemism of the region [35-38]. Inscription on the World Heritage list may not safeguard the greater area against mining. It may, however, bring increased tourism with its associated environmental impacts [39]. In addition, there is controversy over the inscription that was requested to be delayed to incorporate the concerns of local communities living in the region, as well as the sacred groves, which would meet the cultural criteria for inscription [39]. 


\subsection{Shrines and Temples of Nikkō, Japan}

The Shrines and Temples of Nikkō World Heritage site, inscribed in 1999, contains over 100 shrines, temples, and other structures with high architectural and spiritual values, as well as being deeply connected to significant eras in Japanese history (e.g., the Tokugawa shogunate). The site is owned by the religious organisations of Futarasan-jinja, Tōshōgu, and Rinnō-ji, who are also responsible for the site's management [40] (p. 119). The nomination document [40] refers to government and religious bodies that administer different elements of site management (e.g., monitoring, fire prevention, and buffer zone conservation).

Despite being inscribed as a cultural property, the nomination file for this site is explicit about natural values and sacred elements. For example, details about criteria (i) refer to "the harmonious integration of the buildings in a forest", while details about criteria (vi) refer to "the Shinto conception of the relationship of man with nature, in which sacred mountains and forests imbued with spirits are objects of veneration, in a religious practice that is still very much alive today" [40] (p. 1). The buffer zone partially overlaps with other areas protected under national or local ordinances, such as reserved forests, scenic zones, and prioritised landscape control zones [40] (p. 119). Conservation and management activity focuses on the shrines and temples, with natural features protected by various pieces of legislation [40].

Deities are enshrined in parts of the complex, which are still used for sacred rituals and festivals. Rituals scheduled throughout the year include food offerings, incantations, sacred artistic rites, and ritual purification. A specific building is for rituals associated with newborn babies [41].

This World Heritage property was identified in a 2016 report on tourism in Japan as having high tourism potential for foreign visitors [42]. The site is well-known by domestic tourists, given its historical importance. The Andonian et al. [42] study notes there is low awareness of Nikkō among surveyed foreign visitors but-once informed-high appeal. While it is not clear whether or not the study is aimed at Japanese officials working on tourism policy, it contains data that are likely to be used in policy processes.

\subsection{Sacred Mijikenda Kaya Forests, Kenya}

The extensive UNESCO site nomination file of the Sacred Mijikenda Kaya Forests [43], which was inscribed in 2008, provides a detailed account of the eight separate kaya forests and their sacred histories. Kaya means settlement in the Mijikenda languages [44,45]; these were fortified villages, now protected by the Mijikenda community as the sacred abode of their ancestors [45,46]. The settlements range in size from 30 to 300 hectares [47]. Sacred activities and rituals still take place in the kayas:

"[The rituals] reflect a religion which is rooted in the reverence of ancestral spirits and a monolithic deity (Mulungu), a pre-Islamic and pre-Christian belief system found in eastern and southern Africa. Kaya ritual prayers are performed in the local vernacular language and thus also serve as a medium for preserving the local languages and dialects. The preservation of the Mijikenda sacred forests is therefore linked to sustaining their religious traditions and languages" [48] (p. 2).

Management of the kayas is at various levels and through multiple instruments. Kayas that are part of the World Heritage site have been designated either as national monuments or forest reserves, in addition to being covered by various Kenyan statutes. A government agency (National Museums of Kenya-NMK) has the statutory mandate to manage the kayas; they are administered through the Coastal Forest Conservation Unit (CFCU) within NMK. This unit is responsible for the conservation programme, among other tasks, including enforcement and signage relating to the kaya forests [48] (p. 10). At a more local level, each kaya has its own Committee of Elders. NMK work with these Committees, who are "custodians of rituals, the esoteric practices and burials" [48] (p. 11). 
Kaya Kinondo in particular is a focal area for tourism [46,47]. As Nyamweru [46] (p. 281) observed, "the UNESCO World Heritage listing will increase visibility of the kaya forests as tourist destinations, and also strengthen fundraising to support their conservation". According to Nyamweru and Kimaru [49], the number of monthly visitors to Kaya Kinondo ranges from 10 to over 100. A more recent report documented 881 tourists in 2009, 1366 in 2010, and 1266 in 2011, including student visitors [49].

Threats to the Kaya sacred forests include extraction of wood for building poles, sand harvesting, murram quarrying, tourism impacts, theft of traditional grave markers, and clearing for agriculture $[47,49]$.

\subsection{Kinabalu National Park, Malaysia}

Kinabalu National Park was inscribed on the World Heritage list in 2000. In the nomination file [50] (p. 51), sacred aspects of Kinabalu National Park are only mentioned in the 'additional comments' section, which stated:

"Prior to the mid-20th Century, Mount Kinabalu was regarded as a sacred mountain by the Dusan people of the surrounding foothills. The mythology associated with the mountain in former times is one reason the upland region was left intact".

Approximately 15,000 people live around the park [51]. While the phrasing in the nomination files 'additional comments' implies that sacred association with the mountain was a past tradition, the people of Sabah still have a spiritual connection to the mountain [51]. The indigenous Dusun people of the area believe the spirits of their ancestors reside at the top of Mount Kinabalu [51,52].

This site was originally established as a national park in 1964 and is one of the most visited parks in Malaysia, with the number of visitors growing from 829 in 1965 to over 657,027 in 2012 [52]. In 1998, some park services were shifted to a private company, although the park continues to be managed by a statutory body (Sabah Parks), which receives funds from the government to run the state's parks.

After the park was gazetted, local area residents had to pay entrance fees to enter and climb the mountain and reach their sacred sites [52]. Fees to access the park have been steadily increasing, further affecting access by local residents [51]. Currently, there is a tiered system of accommodation pricing for domestic versus foreign visitors. This provides more income to tourism operators for foreign bookings [52]. An International Climbathon takes place every year, which provides revenue representing at least half of the income for the park [52]. Currently, tourism to Mount Kinabalu focuses on natural and geological features, not cultural aspects [53].

Since 2010, but after years of negotiation, Sabah Parks now annually offers one day of free access to the neighbouring Dusun communities to go up the mountain and worship [52]. Jaafar et al. [54] (p. 348) have noted that "an important element of development is to include local communities in tourism planning." It is unclear whether or not this has occurred.

\subsection{Tongariro National Park, New Zealand}

Tongariro National Park has the distinction of being the first World Heritage property with both natural and cultural criteria to be inscribed as an associative cultural landscape. The Park was inscribed in 1990. The nomination file for this property is not publicly available, but associated documents—-such as the Advisory Body assessments—provide details on the nomination. The IUCN assessment for Tongariro National Park stated that, "The area has been occupied by Maoris [sic] since they first arrived from Polynesia and ethnic mythology identifies the mountains in the park with 'tupuna' or god-like ancestors" [55] (p. 2). The land itself was a tuku (offer) to the New Zealand government from Māori in the late 1800s and was made into a national park [55]. 
The sacred nature of this property continues to be a factor in its management both as a national park and as a World Heritage site. While the land is held by the government, the park is currently managed through a co-operative conservation partnership with Ngāti Tūwharetoa, the tangata whenua (people of the land). However, the arrangement has not been satisfactory to local iwi (tribes), and consequently, the park-as part of a larger parcel of land-was the focus of a New Zealand Treaty of Waitangi inquiry process in 1975 [56]. The inquiry found that the Treaty partnership and the partnership embedded in the tuku have not been honoured [57] (p. 1285). The report specifies that-contrary to what was intended with the tuku-Māori have been unable to exercise their authority over the land and the protection of its sacred elements [57].

Tongariro National Park is subject to pressures from tourism and infrastructure development. One of the most popular hiking tracks in New Zealand traverses the sacred mountain; because the trail can be easily accessed and completed in one day, it attracts a high number of tourists. This number has been growing at a rate that has alarmed the government, as well as local iwi who are concerned about impacts on their taonga (treasure) and influences management of the Tongariro National Park and World Heritage site [58].

\subsection{Golden Mountains of Altai, Russian Federation}

The Altai worldview named Bilik is part of one of the oldest living shamanistic traditions in which natural objects (plants, stones, stars, and planets) are known as living beings endowed with the same functional organs as human beings [59]. Despite the fact that shamans have been persecuted and their beliefs dismissed by scientists and the government, the connection between people, land and spirits remains strong. The Altai region is also important for the biodiversity of montane plant and animal species in northern Asia, a number of which are rare and endemic [60]. The nomination file for the property, which was inscribed in 1998, focuses on natural attributes; it has only fleeting mentions of Indigenous peoples living in the area [61] (p. 2), although there is an explicit reference to the folk medicine, culture and religion of Altaians [61] (p. 13).

Notably, the IUCN Advisory Body report on the nomination file recognises the role and importance of local peoples: "These people have co-existed with nature for millennia and have a strong affinity with the natural environment" [61] (p. 48). Indeed, one reviewer commented that the region's important biodiversity is probably not due to purely natural factors but to the millennia of grazing. The Ukok Quiet Zone and Mt. Belukha have particular cultural and religious values for local people. Taking all this into account, there may be reason to consider the Golden Mountains of Altai on cultural grounds as well [60].

The most recent World Heritage Outlook (2020) notes that the site "does not meet the standards set out in the Operational Guidelines for effectively applying a joint management framework", an observation originally made by Debonnet in a WHC/IUCN Reactive Monitoring Mission to the site [62] (p. 4). In response to the Mission, the World Heritage Committee made recommendations, including those explicitly calling for involvement of Indigenous peoples and consideration of cultural heritage in the property [62].

The Golden Mountains of Altai are facing several threats, including tourism development and a gas pipeline [20]. According to Dobson and Maymev [63], some of the heritage conservation practices in the region are highly contested by local people, site guardians, and international heritage practitioners. Plets et al. [64] report on activities that destroyed features and ancestral links - such as excavation and removal from the region of the Ice Maiden, a sacred burial mound.

\section{Discussion}

Our review of sacred natural sites in nine World Heritage sites globally suggests that approaches to identifying and recognising cultural values in the World Heritage system are highly variable, recognising that the inscription process has evolved over time. This finding is in line with the literature and can partly be explained by the different disciplinary backgrounds and practices of cultural and natural heritage practitioners [6] as well as 
a diversity of national heritage and conservation legislation that provides for, or lacks, measures for value assessment [65]. Across the sites we studied, variation exists in the importance given to sacred natural sites based on whether they are acknowledged in the management plan and their custodians represented (see Table 3). For example, the nomination files for the Golden Mountains of Altai and Mount Kinabalu only briefly mention the relationship between Indigenous peoples and the sites. Given the extent and history of Indigenous occupation on and association with the sites, along with the Altai region being a key location of shamanism, the fleeting references in the nomination files are arguably misleading. Similarly, the management plan of Tikal in Guatemala makes mention of past cultural and spiritual significance of the site in terms of its archaeological value. Its relevance for contemporary Indigenous Mayan spirituality and identity is not detailed to the level of appropriate management interventions as required under the 1977 Peace Accords [66]. This is also an oversight of the most recent World Heritage Outlook [4].

Table 3. Analysis of sites.

\begin{tabular}{|c|c|c|c|c|c|}
\hline Country & $\begin{array}{c}\text { World } \\
\text { Heritage Site }\end{array}$ & Type of Site & $\begin{array}{c}\text { Sacred Natural } \\
\text { Sites/Features in } \\
\text { Nomination File? }\end{array}$ & $\begin{array}{c}\text { Sacred Natural } \\
\text { Sites/Features in } \\
\text { Management Plan? }\end{array}$ & $\begin{array}{l}\text { Role of Custodi- } \\
\text { ans/Indigenous } \\
\text { Peoples? }\end{array}$ \\
\hline Australia & $\begin{array}{c}\text { Kakadu } \\
\text { National Park }\end{array}$ & Natural, cultural & $\begin{array}{l}\text { Advisory Bodies } \\
\text { referred to culture and } \\
\text { rituals of Indigenous } \\
\text { peoples }\end{array}$ & $\begin{array}{l}\text { Deeply embedded in } \\
\text { management plan }\end{array}$ & $\begin{array}{l}\text { Clear role of } \\
\text { Indigenous custodians } \\
\text { in management plans }\end{array}$ \\
\hline Greece & Mount Athos & Natural, cultural & $\begin{array}{c}\text { Monasteries, } \\
\text { hermitages, chapels } \\
\text { and sacred art }\end{array}$ & $\begin{array}{l}\text { Unknown- } \\
\text { management plan } \\
\text { under preparation }\end{array}$ & $\begin{array}{l}\text { Self-governed } \\
\text { Orthodox } \\
\text { communities }\end{array}$ \\
\hline Guatemala & $\begin{array}{l}\text { Tikal National } \\
\text { Park }\end{array}$ & Natural, cultural & $\begin{array}{l}\text { Unknown- } \\
\text { nomination file not } \\
\text { public }\end{array}$ & $\begin{array}{l}\text { Mentioned but often } \\
\text { as archaeological } \\
\text { heritage and not as } \\
\text { living heritage }\end{array}$ & $\begin{array}{l}\text { Access and cultural } \\
\text { use is regulated by the } \\
\text { park, limited role for } \\
\text { indigenous people in } \\
\text { management }\end{array}$ \\
\hline India & Western Ghats & Natural & $\begin{array}{l}\text { Multiple mentions of } \\
\text { sacred groves and } \\
\text { river }\end{array}$ & $\begin{array}{c}\text { No separate } \\
\text { management plan } \\
\text { available }\end{array}$ & $\begin{array}{l}\text { Temple committees } \\
\text { manage some sacred } \\
\text { groves }\end{array}$ \\
\hline Japan & $\begin{array}{l}\text { Shrines and } \\
\text { Temples of } \\
\text { Nikkō }\end{array}$ & Cultural & $\begin{array}{l}\text { Sacred natural features } \\
\text { are mentioned }\end{array}$ & Unknown & $\begin{array}{c}\text { Traditional priests are } \\
\text { site custodians. } \\
\text { Unclear for natural } \\
\text { aspects }\end{array}$ \\
\hline Kenya & $\begin{array}{c}\text { Sacred } \\
\text { Mijikenda } \\
\text { Kaya Forests }\end{array}$ & Natural & $\begin{array}{l}\text { Clear reference to } \\
\text { sacred nature of kaya } \\
\text { forests }\end{array}$ & $\begin{array}{l}\text { Sacred aspects } \\
\text { important, managers } \\
\text { work with committee }\end{array}$ & $\begin{array}{l}\text { Managers work with } \\
\text { Committee of Elders } \\
\text { as custodians of kayas }\end{array}$ \\
\hline Malaysia & Kinabalu Park & Natural & $\begin{array}{l}\text { Superficial and } \\
\text { misleading mention }\end{array}$ & $\begin{array}{c}\text { No management plan } \\
\text { available }\end{array}$ & $\begin{array}{l}\text { Local Indigenous } \\
\text { peoples trying to } \\
\text { obtain access }\end{array}$ \\
\hline $\begin{array}{c}\text { New } \\
\text { Zealand }\end{array}$ & $\begin{array}{c}\text { Tongariro } \\
\text { National Park }\end{array}$ & Natural, cultural & $\begin{array}{l}\text { Important component } \\
\text { of listing }\end{array}$ & $\begin{array}{c}\text { Tongariro identified as } \\
\text { sacred }\end{array}$ & $\begin{array}{l}\text { Joint management. } \\
\text { May change with } \\
\text { Treaty settlement }\end{array}$ \\
\hline $\begin{array}{l}\text { Russian } \\
\text { Federation }\end{array}$ & $\begin{array}{l}\text { Golden } \\
\text { Mountains of } \\
\text { Altai }\end{array}$ & Natural & $\begin{array}{c}\text { Brief reference in } \\
\text { country document and } \\
\text { IUCN report }\end{array}$ & Unknown & $\begin{array}{l}\text { Not recognised, as } \\
\text { mentioned in WHC } \\
\text { recommendations }\end{array}$ \\
\hline
\end{tabular}

Site nominations based on cultural, natural, or mixed criteria are intended to be technical decisions of the World Heritage Committee, but often politics plays a role in nominations and in inscription decisions [67]. Inscription is a decision of the World Heritage Committee, and as such, these decisions may be affected by lobbying efforts 
of nomination countries or the particular composition of the Committee $[67,68]$. Three sites-Western Ghats, Kinabalu Park, and Golden Mountains of Altai-were nominated solely on natural criteria, ignoring cultural elements altogether. In the literature, increasing attention is given to the importance of the cultural and spiritual significance of natural heritage, and to biocultural conservation practices [69]. The inscription dates of all three sites (2012, 2000, and 1998, respectively) were at least six years after provisions for cultural landscapes were added to the World Heritage Convention Operational Guidelines. This raises the question of what considerations led the proponent countries to leave out cultural criteria, which are clearly relevant to these properties. One factor may be that the World Heritage Convention lacks a framework to ensure alignment with international law related to human, Indigenous peoples', cultural, and religious rights $[10,11,18,70,71]$. Kuppe [72] argues that western rights of religious freedom could be extended to international religious rights and the rights of Indigenous peoples, thereby creating a legal imperative for the preservation and appropriate management of sacred natural sites. This development would enable the coexistence of multiple legal frameworks including traditional law and spiritual governance and subsequently create a legal status for non-humans and other-than-human persons such as spirits and deities [73]. Conversely, Shrines and Temples of Nikkō was inscribed based on cultural criteria only, ignoring the significant sacredness of natural attributes of the site through which the temples and shrines are inextricably linked in the Shinto religion.

Some World Heritage nomination files are more explicit about the history and role of Indigenous peoples, i.e., Sacred Mijikenda Kaya Forests, Tongariro National Park, Tikal National Park and Kakadu National Park. Notably, there appears to be a stronger and more institutionalised role for Indigenous peoples at these sites. In all four cases, Indigenous peoples have a clear role in the management and governance structure, although their experience of the arrangements may be unsatisfactory (e.g., Tongariro National Park and Tikal National Park). The inclusion of Indigenous peoples in management and governance of protected areas may in part be explained because countries have, after colonisation, seen an increasing amount of court cases resulting in jurisprudence that assists in anchoring Indigenous peoples' rights in national law.

The role of traditional custodians in other sites, e.g., Western Ghats and Shrines and Temples of Nikkō, is less clear. In the case of Nikkō and Mount Athos, the World Heritage and other documents refer to a religious organisation having a role in management and governance, which suggests that the traditional custodians (religious leaders and their institutions) are involved with these activities. This assumption is also supported by the literature that describes the governance of other Shinto shrines in World Heritage sites, such as Mt. Fuji [74] and the Kii Mountain Range [75]. At these sites, not only the religious leaders but also the religious adherents are involved in management and sometimes also governance decisions because they have responsibilities within the religious organisation. Joint management can only work with a people-centred approach [76,77]. Careful efforts must be taken to ensure that deculturalisation does not happen when gazetting protected areas or after inscribing them on the World Heritage list [71,78,79].

With inscription as World Heritage sites, an increase in tourist activity can follow, posing challenges to site managers and custodians of sacred natural sites [80]. A number of the sites examined have been adversely affected by tourism, especially in terms of interactions with the sacred aspects of the site. For example, Tongariro National Park and Kinabalu Park have trekking routes popular with tourists that go through the core of the sacred natural sites. In the case of Kinabalu, the treks are an important source of funding for the site's management. In both cases, there are concerns about the impact of excessive tourism on the sacred natural sites and on the lack of access of local people to their sacred areas [58,81]. Tourism numbers are expected to increase at other sites, such as the Kaya forests and Shrines and Temples of Nikkō, which may adversely affect the spiritual and cultural values of those sites as well. In the Shrines and Temples of Nikkō, the management plan included with the nomination file does not provide clear direction about 
conservation of the cultural and spiritual significance of the sites. In at least one case-the Sacred Mijikenda Kaya Forest - the management plan included with the nomination file provides clear direction about conservation of the cultural and natural heritage. The plan is explicit about threats to the spiritual and cultural values of the kaya forests, and it provides measures such as support to elders, limiting researcher access to certain areas, and ex situ exhibits of Kaya forests and associated culture. The Kaya forests have been under pressure to turn communal land into tourist resorts [82].

\section{Recommendations}

We recognise that our study does not provide a sufficient empirical basis for our conclusions and recommendations to be equally relevant to all other World Heritage sites. Instead, we emphasise their importance to the way World Heritage sites are nominated, managed and governed from the international to the local level. Based on the examination of the nine sites, four actions are proposed: (1) Clearer identification and recognition of sacred natural sites with their associated cultural and spiritual values and explicit links to the appropriate natural and cultural attributes as is customary in World Heritage nominations; (2) recognition and clearly articulated roles for custodians of the sacred natural sites to participate in the governance and management of World Heritage sites; (3) increased uptake of tools, including approaches of religious communities and Indigenous peoples', to support joint management of World Heritage sites that contain sacred natural sites, as appropriate, and (4) prevention of exclusion of custodians and ecological migration by applying inclusive conservation practices through rights-based approaches.

Evolution of the World Heritage Convention has moved in a direction that makes space for cultural landscapes, and in particular, sacred sites and pilgrimage routes [9]. Nonetheless, we found in our subset of World Heritage sites that several nominations did not reflect or recognise the full range of cultural and spiritual values of these sites. A site with sacred and other religious or spiritual importance that has been nominated solely for its natural values can indicate a lack of recognition or even a deliberate act of colonialism and assimilation [83]. Failure to recognise the socio-cultural significance of a site can exacerbate misunderstandings about and discontent with the World Heritage system. Moreover, it can jeopardise the World Heritage nomination and the related site management altogether $[70,71]$.

Recognition of sacred natural sites in the World Heritage system may be low and the extent of their existence may be underestimated for several reasons, including the lack of their assessment according to a recognised typology [80]. In his typology of sacred places, Brockman [84] argues that most sacred World Heritage sites are shrines, tombs, or sites recognised for religious ritual. While these sites may be obvious and included in nominations, other sites may have been overlooked, such as those classified by Brockman [84] (vii) as "the ancestral or mythical homes of the gods" and "places that manifest the energies and mystical powers of nature", which can apply specifically to sacred natural sites as a home to numina or spirits.

Better recognition of the sacred natural sites in nominated World Heritage sites is required - not only by the nominating country but also by the Advisory Bodies that evaluate the nomination dossier and carry out monitoring missions. The sacred natural sites with their associated cultural and spiritual values should be included in the dossier, and a careful assessment should be undertaken if the criteria are not fully reflective of all elements of Outstanding Universal Value. While it is a State Party's choice under which criteria to nominate a site, the Advisory Bodies are in a position to query selection and the extent of consultation with Indigenous peoples and local communities affected by the nomination and possible inscription.

Our analysis also revealed variation in how sites are managed, including in how traditional custodians are involved with management and governance processes. Although the custodians of sacred sites are not explicitly mentioned in the World Heritage Convention, they have been official partners to the management of several World Heritage sites (e.g., 
Sacred Mijikenda Kaya Forests, Tongariro National Park, Shrines and Temples of Nikkō, and Mount Athos). In other sites where traditional custodians were living near or in the sites, they appear to be minimally or not involved in the official management and governance plans for the sites (e.g., Kinabalu Park, Golden Mountains of Altai, and Tikal).

Steps can be taken to improve the understanding of the role of traditional custodians in the Convention, and State Parties can be encouraged to develop management plans that ensure meaningful involvement of custodians in management and governance as well as the recognition of all sacred natural sites, including those that do not meet the criteria for OUV. We suggest people-centred collaborative activities, such as regular dialogues between custodians of sacred natural sites, site managers, decision makers, and the Convention's Advisory Bodies based on the elaboration and implementation of the Statement on the Protection of Religious Properties within the Framework of the World Heritage Convention, which now serves as a basis for further development of the UNESCO Initiative on Heritage of Religious Interest [85].

Similarly, the role of sacred natural site custodians can be supported more explicitly within the World Heritage Convention in other ways. The first would be by including Indigenous custodians in the International Indigenous People's Forum on World Heritage, an initiative launched in 2018 [86]. This initiative is arguably a permutation of the 'World Heritage Indigenous Peoples Council of Experts', which had been proposed in 2000 but was rejected by States' Parties [87]. The second suggestion would be to include custodians of sacred natural sites and the issues they represent in technical committees, working groups, and in the work of the Advisory Bodies. This would assist in operationalising the World Heritage Convention's strategic direction for "communities". For example, the IUCN World Commission on Protected Areas' Specialist Group on Cultural and Spiritual Values of Protected Areas (CSVPA) has developed the IUCN UNESCO Best Practice Guidelines for Sacred Natural Sites [2] and the IUCN Best Practice Guidelines in Cultural and Spiritual Significance of Nature [88]. CSVPA also hosts and supports the Delos Initiative focusing on sacred natural sites in technologically developed countries and the Sacred Natural Sites Initiative supporting the custodians of Indigenous sacred natural sites [65]. These materials and programmes are valuable and can meaningfully inform the work of the committees and groups.

In addition, during its General Assembly in 2005, ICOMOS initiated an international thematic programme on World Heritage sites of religious significance [85] and revived this idea in 2011 through resolution 17GA 2011/35 on protection and enhancement of sacred heritage sites, buildings and landscapes [89]. It is important for site managers to identify appropriate actions and assist with creating an environment for custodians, local communities, and other stakeholders where they can represent themselves and liaise their interests; Wild and Mcleod [2] offer the following six principles (Table 4).

Table 4. The six principles of the IUCN UNESCO Guidelines on sacred natural sites [2] (p. 21).

\begin{tabular}{|c|c|}
\hline Principle 1 & Recognise sacred natural sites already located in protected areas \\
\hline Principle 2 & $\begin{array}{l}\text { Integrate sacred natural sites located in protected areas into planning } \\
\text { processes and management programmes }\end{array}$ \\
\hline Principle 3 & Promote stakeholder consent, participation, inclusion and collaboration \\
\hline Principle 4 & Encourage improved knowledge and understanding of sacred natural sites \\
\hline Principle 5 & $\begin{array}{l}\text { Protect sacred natural sites while providing appropriate management } \\
\text { access and use }\end{array}$ \\
\hline Principle 6 & $\begin{array}{l}\text { Respect the rights of sacred natural site custodians within an appropriate } \\
\text { framework of national policy }\end{array}$ \\
\hline
\end{tabular}

These guidelines can be integrated into the management plans of World Heritage sites that have sacred natural sites; activities such as inclusive training workshops based on the principles can ensure full participation and involvement of traditional custodians. As Ami 
and Hamzah [51] (p. 63) remarked about Kinabalu National Park and World Heritage site, "The capacity of local and indigenous communities should also be enhanced so that they function as effective joint custodians of protected areas". In no cases should Indigenous people or nomadic users of sites be displaced as part of World Heritage site nomination [71].

\section{Conclusions}

Sacred natural sites are different from many other cultural sites because of their spiritual significance, which is typically directly linked to natural attributes and features often through resident spirits, deities or gods. As they are also significant to specific ethnic, religious or cultural groups, this makes it complex for their value to be articulated and recognised in the context of the World Heritage system's requirement for sites to have OUV. Sacred natural sites and their custodians can play a significant role in the governance and management of the landscape in which they are embedded. Traditional governance systems, including roles for spirits and more-than-human persons, require coexistence in site management and governance. Sacred natural sites and their multiple traits and qualities should be better recognised in the preparation of the World Heritage site nomination files, the governance and management of the World Heritage site, and the monitoring missions carried out by the Advisory Bodies as well as the World Heritage Outlook. Making the cultural and spiritual dimensions of nature more explicit in the governance and management of World Heritage sites enables recognition of the connections between natural and cultural heritage values. Recognition of sacred natural sites and their custodians can strengthen the credibility and coverage of the World Heritage system.

Author Contributions: Conceptualisation, methodology-B.V., A.O. and W.J. Writing—original draft preparation, B.V. Following drafts, including analysis-W.J., A.O. and B.V. All authors have read and agreed to the published version of the manuscript.

Funding: This research received no external funding.

Data Availability Statement: All relevant data are presented in the article.

Acknowledgments: The authors are grateful for the assistance of Leticia Leitão, the role of custodians of the sites, and the comments from anonymous reviewers.

Conflicts of Interest: The authors declare no conflict of interest.

\section{References}

1. UNESCO. Convention Concerning the Protection of the World Cultural and Natural Heritage; UNESCO: Paris, France, 1972; Volume 1, pp. 135-145. [CrossRef]

2. Wild, R.; Mcleod, C. Sacred Natural Sites Guidelines for Protected Area Managers; IUCN: Gland, Switzerland, 2008.

3. UNESCO. International Seminar on The Role of Religious Communities in the Management of World Heritage Properties, Kyiv. Available online: http://whc.unesco.org/en/religious-sacred-heritage/ (accessed on 5 August 2020).

4. IUCN. Tikal National Park. In 2020 Conservation Outlook Assessment; IUCN World Heritage, Ed.; IUCN: Gland, Switzerland, 2020.

5. UNESCO. Adoption of Retrospective Statements of Outstanding Universal Value; UNESCO: Paris, France, 2013.

6. Leitão, L.; Wigboldus, L.; Bourdin, G.; Badman, T.; Tolnay, Z.; Mthimkhulu, O. Connecting practice: Defining new methods and strategies to further integrate natural and cultural heritage under the World Heritage Convention. In Cultural and Spiritual Significance of Nature in Protected Areas: Governance, Management and Policy; Verschuuren, B., Brown, S., Eds.; Routledge: London, UK, 2019; pp. 151-163.

7. UNESCO. The Criteria for Selection. Available online: http://whc.unesco.org/en/criteria/ (accessed on 4 October 2021).

8. UNESCO. Report of the 16th Session of the World Heritage Committee. In Document WHC-92/CONF.002/12; UNESCO: Santa Fe, NM, USA, 1992

9. Finke, G. Linking Landscapes: Exploring the Relationships between World Heritage Cultural Landscapes and IUCN Protected Areas; IUCN: Gland, Switzerland, 2013.

10. Brown, J.; Hay-Edie, T. COMPACT: Engaging Local Communities in the Stewardship of World Heritage; World Heritage Papers 40; UNESCO: Paris, France, 2013.

11. Sinding-Larsen, A.; Bille Larsen, P. Report: The Advisory Body "Our Common Dignity Initiative" on Rights-Based Approaches in World Heritage: Taking Stock and Looking Forward; ICOMOS Norway: Oslo, Norway, 2017.

12. Verschuuren, B.; Wild, R.; McNeely, J.; Oviedo, G. Sacred Natural Sites: Conserving Nature and Culture; Earth Scan: London, UK, 2010. 
13. Dudley, N. Guidelines for Applying Protected Area Management Categories; IUCN: Gland, Switzerland, 2008.

14. Schaaf, T.; Rossler, M. Sacred Natural Sites, Cultural Landscapes and UNESCO's Action. In Sacred Natural Sites: Conserving Nature and Culture; Verschuuren, B., Wild, R., Mcneely, J., Oviedo, G., Eds.; Earth Scan: London, UK, 2010.

15. Palmer, M. Faiths and the Environment; World Bank: Washington, DC, USA, 2005.

16. Putney, A. Building cultural support for protected areas through sacred natural sites. In Friends for Life; Mcneely, J., Ed.; IUCN: Gland, Switzerland, 2005; pp. 129-140.

17. Verschuuren, B. How the cultural, spiritual and philosophical underpinnings of sacred natural sites can make conservation in Asia more effective and sustainable. In Asian Sacred Natural Sites: Philosophy and Practice in protected Areas and Conservation; Verschuuren, B., Furuta, N., Eds.; Routledge: London, UK, 2016; pp. 297-309.

18. Ekern, S.; Logan, W.; Sauge, B.; Sinding-Larsen, A. Human rights and World Heritage: Preserving our common dignity through rights-based approaches to site management. Int. J. Herit. Stud. 2012, 18, 213-225. [CrossRef]

19. Meskell, L. UNESCO's World Heritage Convention at 40. Curr. Anthropol. 2013, 54, 483-494. [CrossRef]

20. Badenkov, Y. Transboundary issues in the Altai. Mt. Res. Dev. 2011, 31, 390-391. [CrossRef]

21. Russel Bernard, H. Research Methods in Anthropology: Qualitative and Quantitative; Rowman \& Littlefield: Lanham, MA, USA, 2018.

22. Director of National Parks. Kakadu National Park: Management Plan 2016-2026; Australia Department of the Environment and Energy: Canberra, Australia, 2016.

23. UNESCO; ICOMOS. Advisory Body Evaluation; UNESCO: Paris, France, 1981. Available online: https://whc.unesco.org/ document/155059 (accessed on 5 August 2021).

24. UNESCO; IUCN. Advisory Body Evaluation; UNESCO: Paris, France, 1981. Available online: https://whc.unesco.org/document/ 155060 (accessed on 5 August 2021).

25. Australia Department of the Environment and Energy. Statement of Jeffrey Lee to the 35th session of the World Heritage Committee. Available online: https: / / www.environment.gov.au/system/files/pages/bf8cd0a7-1fd2-4202-a62d-b998a4d93cb7 / files/jeffery-lee-statement.pdf (accessed on 10 October 2021).

26. ICOMOS. Advisory Body Evaluation, No 454. Mt. Athos. Available online: https://whc.unesco.org/document/153517 (accessed on 10 October 2021).

27. Philippou, I.; Kontos, K. The protected area of the peninsula of the Athos Holy Mountain, Halkidiki, Greece. In The Sacred Dimensions of Protected Areas; Papayannis, T., Mallarach, J.-M., Eds.; IUCN: Gland, Switzerland; Med INA: Athens, Greece, 2009; pp. 107-127.

28. Kakouros, P. Landscape conservation actions on Mount Athos. In The Sacred Dimensions of Protected Areas; Papayannis, T., Mallarach, J.-M., Eds.; IUCN: Gland, Switzerland; Med INA: Athens, Greece, 2009; pp. 127-137.

29. ICOMOS. Nomination file Mount Athos. 1988. Available online: https:/ / whc.unesco.org/document/153517 (accessed on 10 October 2021).

30. UNESCO. Periodic Reporting Cycle II, Mount Athos. Available online: https://whc.unesco.org/document/164199 (accessed on 10 October 2021)

31. UNESCO. Tikal National Park (Guatemala), CC-79/CONF.003/13. In Report of the 3rd Session of the World Heritage Committee (Luxor, Egypt, 1979); Äë̈̈, İ., Ed.; UNESCO: Paris, France, 1979.

32. UNESCO. IUCN Review, World Heritage Nomination, Tikal National Park; UNESCO: Paris, France. Available online: https: / / whc.unesco.org/document/153940 (accessed on 10 October 2021).

33. Chan, R.M.; Secaira, E.; Molina, M.E. (Eds.) Plan Maestro del Parque Nacional Tikal 2003-2008; Ministerio de Cultura y DeportesDirección del Patrimonio Cultural y Natural-Parque Nacional: Ciudad Guatemala, Guatemala, 2003.

34. Government of India. Serial Nomination of the Western Ghats of India: Its Natural Heritage for Inscription on the world Natural Heritage List. Available online: http://whc.unesco.org/uploads/nominations/1342rev.pdf (accessed on 10 October 2021).

35. Bhagwat, S.; Kushalappa, C.G.; Williams, P.H.; Brown, N.D. A Landscape Approach to Biodiversity Conservation of Sacred Groves in the Western Ghats of India. Conserv. Biol. 2005, 19, 1853-1862. [CrossRef]

36. Das, A.; Krishnaswamy, J.; Bawa, K.S.; Kiran, M.C.; Srinivas, V.; Kumar, N.S.; Karanth, K.U. Prioritisation of conservation areas in the Western Ghats, India. Biol. Conserv. 2006, 133, 16-31. [CrossRef]

37. Ormsby, A. Analysis of local attitudes toward the sacred groves of Meghalaya and Karnataka, India. Conserv. Soc. 2013, 11, 187-197. [CrossRef]

38. Ray, R.; Chandran, M.D.S.; Ramachandra, T.V. Biodiversity and ecological assessments of Indian sacred groves. J. For. Res. 2014, 25, 21-28. [CrossRef]

39. Ormsby, A.; Jackson, W.; Bhagwat, S. Can World Heritage Status Help Protect Sacred Sites in Asia? In Asian Sacred Natural Sites: Philosophy and Practice in protected Areas and Conservation; Verschuuren, B., Furuta, N., Eds.; Routledge: London, UK, 2016; pp. 41-54.

40. UNESCO. Nomination file for Shrines and Temples of Nikkō; UNESCO: Paris, France, 1999.

41. 'Nikkō Tōshōgu Shrine'. Shrine Overview. n.d. Available online: https://www.toshogu.jp/english/ (accessed on 5 August 2021).

42. Andonian, A.; Kuwabara, T.; Yamakawa, N.; Ishida, R. The Future of Japan's Tourism: Path for Sustainable Growth Towards 2020; McKinsey Japan and Travel, Transport and Logistics Practice: Osaka, Japan, 2016; Volume 10, p. 2018.

43. UNESCO. Nomination file for the Sacred Mijikenda Kaya Forests; UNESCO: Paris, France, 2008. 
44. Kibet, S.; Nyamweru, C. Cultural and biological heritage at risk; the case of the Rabai Kaya forests in Coastal Kenya. J. Hum. Ecol. 2008, 24, 287-295. [CrossRef]

45. Nyamweru, C.; Kibet, S.; Pakia, M.; Cooke, J. The Kaya forests of coastal Kenya: 'Remnant patches' or dynamic entities. In African Sacred Groves: Ecological Dynamics \& Social Change; Sheridan, M., Nyamweru, C., Eds.; James Currey: Oxford, UK, 2008.

46. Nyamweru, C. Natural cultural sites of Kenya: Changing contexts, changing meanings. J. East. Afr. Stud. 2012, 6, 270-302. [CrossRef]

47. Abungu, G.O.; Githitho, A. Homelands of the Mijikenda people: Sacred Mijikenda Kaya Forests, Kenya (kor). In World Heritage: Benefits Beyond Borders; Galla, A., Ed.; Cambridge University Press: Cambridge, UK, 2012; pp. 147-157.

48. UNESCO. Advisory Body Evaluation (ICOMOS) The Mijikenda Kaya Forests (Kenya); UNESCO: Paris, France, 2008.

49. Nyamweru, C.; Kimaru, E. The contribution of ecotourism to the conservation of natural sacred sites: A case study from coastal Kenya. J. Study Relig. Nat. Cult. 2008, 2, 327-350. [CrossRef]

50. UNESCO. Nomination file for Kinabalu Park. Available online: http:/ / whc.unesco.org/uploads/nominations/1012.pdf (accessed on 10 october 2021).

51. Ami, J.; Hamzah, A. Incorporating sacred places and traditional values in the management of protected areas for conservation and ecotourism. J. Hosp. Tour. 2013, 10, 53-64.

52. Goh, H.C.; Yusoff, M.M. Sustaining tourism development in protected areas. A case of Kinabalu Park. Int. J. Trade Econ. Financ. 2010, 1, 179-183. [CrossRef]

53. Bidder, C.; Kibat, S.A.; Fatt, B.S. Cultural interpretation toward sustainability: A case of Mount Kinabalu. Procedia Soc. Behav. Sci. 2016, 224, 632-639. [CrossRef]

54. Jaafar, M.; Kayat, K.; Tangit, T.M.; Yacob, M.F. Nature-based rural tourism and its economic benefits: A case study of Kinabalu National Park. Worldw. Hosp. Tour. Themes 2013, 5, 342-352. [CrossRef]

55. UNESCO. World Heritage Nomination-IUCN Summary: Tongariro National Park (New Zealand); UNESCO: Paris, France, 1990.

56. New Zealand Department of Conservation. History and Culture. Available online: https://www.doc.govt.nz/our-work/ heritage/ (accessed on 10 october 2021).

57. Waitangi Tribunal. Te Kāhui Maunga: The National Park District Inquiry Report. Available online: https://forms.justice.govt.nz/ search/WT/reports.html (accessed on 10 October 2021)

58. Hampton, L. Tongariro Crossing Struggling to Cope with Hordes of Tourists. Available online: https://www.newshub.co.nz/ home/new-zealand/2017/02/tongariro-crossing-struggling-to-cope-with-hordes-of-tourists.html (accessed on 5 August 2021).

59. Shodoev, N. Spiritual Wisdom from the Altai Mountains; John Hunt Publishing: Winchester, UK, 2012.

60. UNESCO. Advisory Body Evaluation, IUCN Technical Evaluation, Golden Mountains of Altai. Available online: https://whc. unesco.org/document/154219 (accessed on 10 October 2021).

61. UNESCO. Nomination file for Golden Mountains of Altai. Available online: https://whc.unesco.org/uploads/nominations/76 8rev.pdf (accessed on 10 October 2021).

62. UNESCO. Decision: Golden Mountains of Altai (Russian Federation). Available online: https://whc.unesco.org/en/decisions/ 7005 (accessed on 10 October 2021).

63. Dobson, J.; Mamyev, D. Sacred Valley, Conservation Management and Indigenous Survival: Uch Enmek Indigenous Nature Park, Altai. In Sacred Natural Sites: Conserving Nature and Culture; Verschuuren, B., Wild, R., Mcneely, J., Oviedo, G., Eds.; Earth Scan: London, UK, 2010.

64. Plets, G.; Konstantinov, N.; Soenov, V.; Robinson, E. Repatriation, doxa, and contested heritages: The return of the Altai Princess in an international perspective. Anthropol. Archeol. Eurasia 2013, 52, 73-98. [CrossRef]

65. Brown, S.; Verschuuren, B. Cultural and spiritual significance of nature in protected and conserved areas. In Cultural and Spiritual Significance of Nature in Protected Areas: Governance, Management and Policy; Verschuuren, B., Brown, S., Eds.; Routledge: London, UK, 2018; pp. 1-13.

66. Conciliation Resources. Negotiating Rights: The Guatemalan Peace Process. An international Review of Peace Initiatives Accord. Available online: https:/ / rc-services-assets.s3.eu-west-1.amazonaws.com/s3fs-public/02_Guatemala.pdf (accessed on 10 October 2021).

67. Meskell, L. States of Conservation: Protection, Politics, and Pacting within UNESCO's World Heritage Committee. Anthropol. Q. 2014, 87, 217-243. [CrossRef]

68. Meskell, L. The rush to inscribe: Reflections on the 35th Session of the World Heritage Committee, UNESCO Paris, 2011. J. Field Archaeol. 2012, 37, 145-151. [CrossRef]

69. Verschuuren, B.; Brown, S. Cultural and Spiritual Significance of Nature in Protected Areas; Routledge: London, UK; New York, NY, USA, 2018

70. Oviedo, G.; Puschkarsky, T. World Heritage and rights-based approaches to nature conservation. Int. J. Herit. Stud. 2012, 18, 285-296. [CrossRef]

71. Disko, S.; Tugendhat, H. World Heritage Sites and Indigenous Peoples' Rights; IWGIA: Copenhagen, Denmark; Forest Peoples Programme: Anderen, The Netherlands; Gundhjeihmi Aboriginal Corporation: Jabiru, NT, Australia, 2014

72. Kuppe, R. Religious freedom law and the protection of sacred sites. In Permutations of Order; Routledge: London, UK, 2016; pp. 49-66. 
73. Studley, J.; Bleisch, W.V. Juristic personhood for sacred natural sites: A potential means for protecting nature. PARKS J. 2018, 24, 81-96. [CrossRef]

74. Ono, T.; Hongo, T.; Yamamoto, K.; Furuta, N. Mount Fuji's history as a spiritual realm and means for its preservation. In Asian Sacred Natural Sites: Philosophy and Practice in Protected Areas and Conservation; Verschuuren, B., Naoya, F., Eds.; Routledge: London, UK, 2016; pp. 181-192.

75. Motonaka, M. Sacred Sites and Pilgrimage Routes in the Kii Mountain Range in the Mie, Nara and Wakayama Prefectures, Japan. In Protected Areas and Spirituality; Mallarach, J.-M., Papayannis, T., Eds.; IUCN: Gland, Switzerland; Publicaciones de l'Abadia de Montserrat: Montserrat, Spain, 2007; pp. 279-288.

76. Ma, S.; Ma, S. The Environmental Justice in Ecological Immigration A Case Study of Sanjiangyuan Area. Archit. Res. 2015, 17, 147-152. [CrossRef]

77. Foggin, J.M. Depopulating the Tibetan grasslands: National policies and perspective for the future of Tibetan herders in Qinghai Province, China. Mt. Res. Dev. 2008, 28, 26-31. [CrossRef]

78. Dowie, M. Conservation Refugees: The Hundred-Year Conflict between Global Conservation and Native Peoples; MIT Press: Cambridge, MA, USA, 2009.

79. Tauli-Corpuz, V.; Alcorn, J.; Molnar, A.; Healy, C.; Barrow, E. Cornered by PAs: Adopting rights-based approaches to enable cost-effective conservation and climate action. World Dev. 2020, 130, 104923. [CrossRef]

80. Shackley, M. Sacred World Heritage Sites: Balancing Meaning With Management. Tour. Recreat. Res. 2001, 26, 5-10. [CrossRef]

81. Esfahani, M.; Musa, G.; Khoo, S. The influence of spirituality and physical activity level on responsible behaviour and mountaineering satisfaction on Mount Kinabalu, Borneo. Curr. Issues Tour. 2017, 20, 1162-1185. [CrossRef]

82. Kihima, B.O.; Kimaru, E. Kaya Kinondo community ecotourism project in Kenya: A decade later. East Afr. J. Hosp. Leis. Tour. 2013, $1,12-24$.

83. Lee, E. From boardroom to kitchen table: Shifting the power seat of Indigenous governance in protected area management. Aust. Aborig. Stud. 2016, 81-93.

84. Brockman, N.C. Encyclopedia of Sacred Places, [2 Volumes]; ABC-CLIO: Santa Barbara, CA, USA, 2011.

85. UNESCO. UNESCO Initiative on Heritage of Religious Interest. Available online: https://whc.unesco.org/en/religious-sacredheritage/ (accessed on 15 December 2021).

86. IIPFWH. The International Indigenous Peoples' Forum on World Heritage. Available online: https://iipfwh.org/ (accessed on 20 November 2021).

87. Meskell, L. UNESCO and the Fate of the World Heritage Indigenous Peoples Council of Experts (WHIPCOE). Int. J. Cult. Prop. 2013, 20, 155-174. [CrossRef]

88. Verschuuren, B.; Mallarach, J.-M.; Bernbaum, E.; Spoon, J.; Brown, S.; Borde, R.; Brown, J.; Calamia, M.; Mitchell, N.; Infield, M. Cultural and Spiritual Significance of Nature: Guidance for Protected and Conserved Area Governance and Management, no. 32; IUCN: Gland, Switzerland, 2021.

89. ICOMOS. Québec Declaration on the Preservation of the Spirit of Place; ICOMOS: Québec, QC, Canada; Paris, France, 2008. 